DOI: 10.15503/jecs20141-312-319

312

Local cultures and societies

\title{
THE ALBANIAN ORGANIZATION AND ORGANIZATIONAL STRUCTURE - THE CHALLENGES OF THE ADAPTATION TO THE DYNAMIC REALITY
}

\author{
LUDMILLA SHKURTI \\ Lecturer at Economic Department, Wisdom University, \\ Rruga e "Kavajës" "Condor Center" Tirana, Albania \\ E mail address: ludmilla.shkurti@gmail.com
}

ABSTRACT

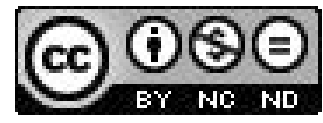

There were 78,400 enterprises active in Albania in 2011, employing 180,800 people, of which $47 \%$ worked in 1,684 enterprises employing more than 20 people. These last enterprises represented 61 percent of the total turnover, and 75 percent of the total investments. These enterprises are predominantly in the industrial and construction sectors. Enterprises with 1-4 employees represent 91 percent of the total enterprises, and represent 14 percent of total turnover. Small enterprises are dominant in the service sector. Business in Albania is currently operating in a global environment, which has a great impact on the theory or practice of organizations, and also on the working behaviour of employees. This already complex environment, which is becoming increasingly dynamic, and growing competition, are also changing the way in which work is organized, as well as the solutions. Great opportunities are arising from a better understanding of Albanian contemporary organizations and the work environment. To take advantage of these opportunities, the trends regarding the relationship between organizational design and design work should be studied and identified. The aim is to identify the potential patterns and the current trends and tendencies in Albanian organization design, providing useful knowledge in the field of Albanian business practices, and future challenges for research in this direction.

Keywords: Structure, organization, strategy, concurrence, dynamic ambient

\section{INTRODUCTION}

Organizational design is a young field that incorporates many concepts and approaches. In organizational design literature to date, there seems to have been only two ways of doing things in this field either to be so general and so simple that the various interpretations do not yield practical design implications, or to be so detailed and specific that generalization to other situations is almost impossible. (Burton, Obel, 2004).

The conventional design is largely static, and while it can be very useful to managers as a conceptual device for constructing a new organization it does not offer the practical guidance they need (Burton, Eriksen, Døjbak Håkonsson, \& Snow, 2006). There are several definitions to describe business organizations, one 
of which, referred to by Richard L. Daft and Ann Armstrong asserts that business organizations are:

- Social entities which are

- Directed by goals

- Designed as deliberately structured and coordinated systems activities, and

- Connected to the external environment (Daft, \& Armstrong, 2012).

Abstract reasoning is needed to be able to anticipate future business challenges. This is only a starting point, a foundation for the design and management of organizations that respond effectively to the new reality of relentless competition and changing customer expectations (Rummler, \& Brache, 1995).

The concepts of the strategy and the broader concept of the strategic management are complex. Researches pointed out that the structure of firms could be predicted with some reliability from their chosen strategy (Radzi, Jamaluddin, Zahari, Amran, \& Othman, 2007). New organizational forms and managerial philosophies have been studied, introduced and proposed. Due to some significant changes in the environment, the traditional organizational boundaries have been changed significantly, requiring new ideas and approaches (Tomislav, 2011).

Managers deliberately structure and coordinate organizational resources to achieve the goal of the organization. Today, most organizations are struggling for a more horizontal coordination of work activities, often using teams of employees from different functional areas to work together on projects. The boundaries between departments, and between organizations, are becoming more flexible and fluid as companies face the need to react quickly to changes in the external environment. An organization cannot exist without interaction with its customers, suppliers, competitors, and other elements of the external environment. Some companies also co-operate, with their competitors mutually benefitting, exchanging information and technology.

\section{THE RESEARCH QUESTIONS}

The research questions could help us to understand the Albanian context about organizational structuring process. It offers more insight regarding:

a) Where are Albanian organizations going in the context of structuring and why?

b) What are the factors which have the greatest impact on organizational structuring in Albania?

c) What are the challenges for structuring organizational decision conditions in Albania?

\section{THE RAISED HYPOTHESIS}

The hypothesis (the main one) aim to test first the Albanian context regarding awareness of management class in terms of structure - strategy importance rapport and then to find out the main factor and / or other ones which have more impact on the Albanian organizational business structuring process and design. 
H0 - There is a little awareness in Albanian business of the importance of organizational structure according to the strategy.

H01 - There is not yet awareness in Albania of the importance of organizational structure according to the strategy.

H02 - expected deliberations to design the works is conditioned by several factors (variables) but the main one is:

The organizational financial ability

Sub hypotheses

1. New flexible organizational forms in response to environmental changes are being developed in Albania, alongside traditional models.

2. Some of the factors expected to constrain the organizational structure in Albania are:

- Strategy

- Technology

- Digitalization

- Globalization

- Competition

- Change of the consumer demand

\section{THE METHODOLOGY USED IN THE PAPER}

Since approach and systemic thinking are even more dominant in the business and academic world, many researchers in the field are using analysis of the relationships between various intertwined trends and are applying new tendencies in daily business practice.

It is in compliance with the model of the interaction between behavior and characteristics of the micro-level work, and organizational structure and design at the macro level.

In addition, a systemic approach provides a holistic evaluation in a more abstract thinking in relational terms, emphasizing that everything is connected to everything else and it is often valuable to the business model in terms of turnover and feed back (Harmon, 2003).

The methodology consists of a combination of primary data with secondary ones. A significant proportion of secondary data was provided through the use of the electronic libraries of various universities - mainly American, but also European ones. Also, the data from researches made by the Vlora District institutions such as Municipality, Prefecture, Chamber of Commerce and Industry Vlore, etc. is used.

Private firms in Albanian cities such as Vlore, Fier, Lushnje, Saranda, Durres and Tirana are used to study the structure model, and to complete the comparison a questionnaire was drawn up.

The questionnaire was designed to be addressed to the general managers of private firms, which were tested those of functions, or of line ones, as well as to specialists. Questionnaires are standardized and uniform for all subjects included in the study. Questionnaires were distributed to 300 firms during the second half 
of 2011 and during 2012, 2013. Distribution of the questionnaire was made by personally interviewing 5-6 persons in each firm or via e-mail. The questionnaires took into consideration variables such as firm size, the year of their creation, knowledge of the structure and the organization's overall strategy, linking strategy organization for structuring future challenges.

\section{ON THE GROUND RESEARCH TOOLS}

The methodology consists of a combination of primary data with secondary ones. To fulfill the task of research on the ground, it is important to respect the methodology using these tools:

1. Descriptive Statistics

2. Questionnaires

3. Meetings and round tables

4. Internet websites

5. Data from regional institutions at local level
a) INSTAT
b) Chamber of Commerce
c) Experts in the field

The objectives of the paper would help to have a framework which aims to identify the potential patterns and the current trends and tendencies in Albanian organization design, providing useful knowledge in the field of Albanian business practices, and future challenges for research in this direction. Doing so they try:

1. To analyze the overall framework of the organizational practice (evidencing the situation) .

2. To identify the challenges facing business in the context of organizational structuring.

3. To identify trends which business is following in the context of organizational structuring.

4. To contribute to the diagnosis of the Albanian problem.

Abstract reasoning is needed to be able to anticipate future business challenges. This is only a starting point, a foundation for the design and management of organizations that respond effectively to the new reality of relentless competition and changing customer expectations (Rummler, \& Brache, 2013). Although ultimately the future remains unknown, its roots are in the present and in the past. In other words, we can identify many of the major developments in the coming years, from what we see today.

Current trends in science and technology, economic development, government policies, social structure, demographics, and lifestyle will certainly shape the business environment for the remainder of the decade (Grant, 2009).

Although it is almost impossible to define all the possible factors that directly affect modern business practice indirectly the various trends in organizational and work level, it is necessary to mention those most important. 


\section{RESULTS AND DISCUSSION}

The statistical data: 200 (returned) questionnaires (from 300 distributed) have been analyzed, with a distribution of business activity as follows:

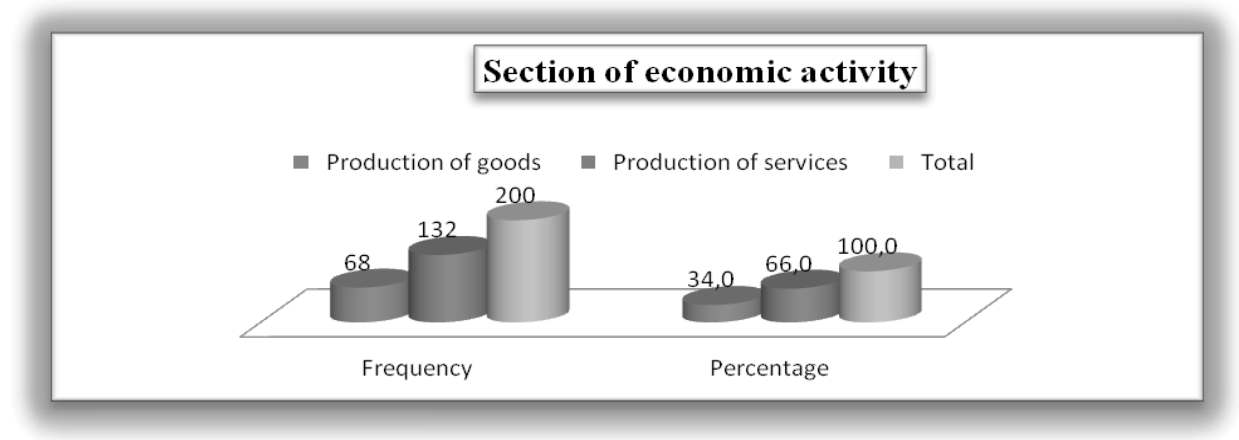

Fig.1. Businesses by the Section of Economic Activity.

Source: Authors` research.

Since the questionnaires are part of a larger research regarding Albanian business organizational structure, to confirm the hypothesis of this paper, regarding awareness of management class in terms of structure - strategy importance rapport $(\mathrm{H} 0, \mathrm{H} 1)$ and then to find out the main factor and / or other ones which have more impact on the Albanian organizational business structuring process and design, (H2 and sub hypothesis), we need to stop at only no. 14 19, 23,and 24 of the questionnaire.

Question no 14: How much is based the establishing organizational structure (labour division) to:

- the financial ability

- the other firms experiences (copied)

- the spontaneous need shifted to experience/routine

- the casualty

According to the respondents' opinion, the main factor and / or other ones which have more impact on the Albanian organizational business structuring process and design are as follow:

Tab. 1. Respondents' Perception about Organizational Structure Factores.

\begin{tabular}{|l|c|c|}
\hline \multicolumn{2}{|c|}{ Question no 14 : Respondents' Perception about Organizational Structure Factores } \\
\hline Alternatives & Frequency & Percent \\
\hline 1 Financial ability & 72 & 36.0 \\
\hline 2 Casualty & 25 & 12.5 \\
\hline 3 Copied from the other experiences & 65 & 32.5 \\
\hline 4 Shift of the spontaneous need to exp. / routine & 30 & 15.0 \\
\hline 5 No response & 8 & 4.0 \\
\hline
\end{tabular}

Source: Authors` research. 


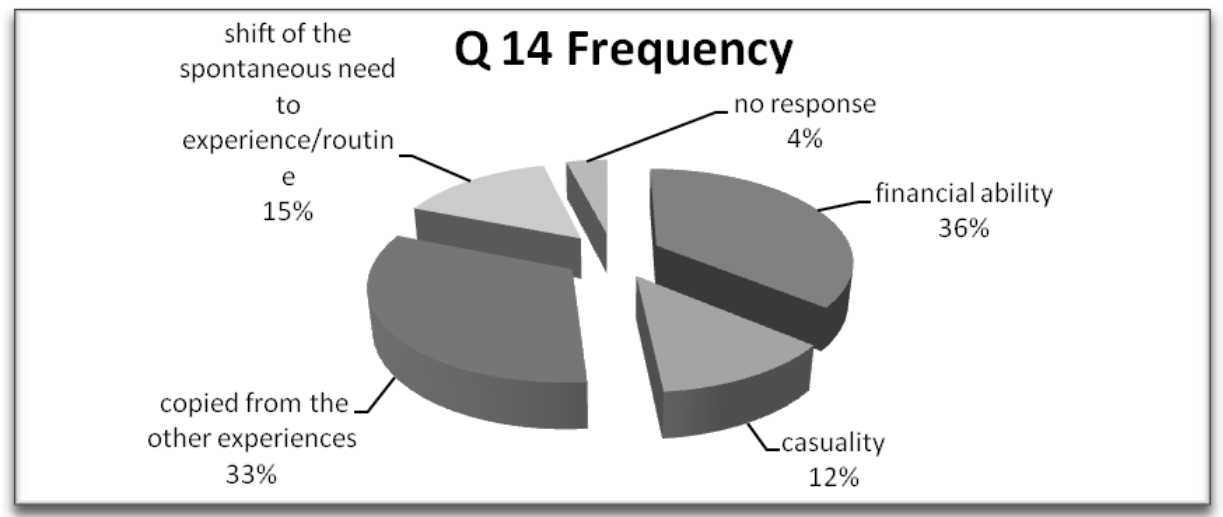

Fig. 2. Respondents' Perception about Organizational Structure Factores (question no 14). Source: Authors` research.

Question no 19: Which factors have had impact on the new or changed structure in your company?

The analyzed questionnaires to the surveyed businesses in the Vlora region evidence the impact of many factors on organizational structures changes (see the graph and table 2).

Most significant in testing the main hypothesis is that there is a little awareness in Albanian business of the importance of organizational structure according to the strategy. Only $23.5 \%$ of the respondents think that strategy is aligned to structure.

Instead of this (according to the data) I could say that the bigger impact on the new or changed structure in Albanian companies has the business competition (26\%).Another factor with impact, third in rank $(17 \%)$ is the technology.

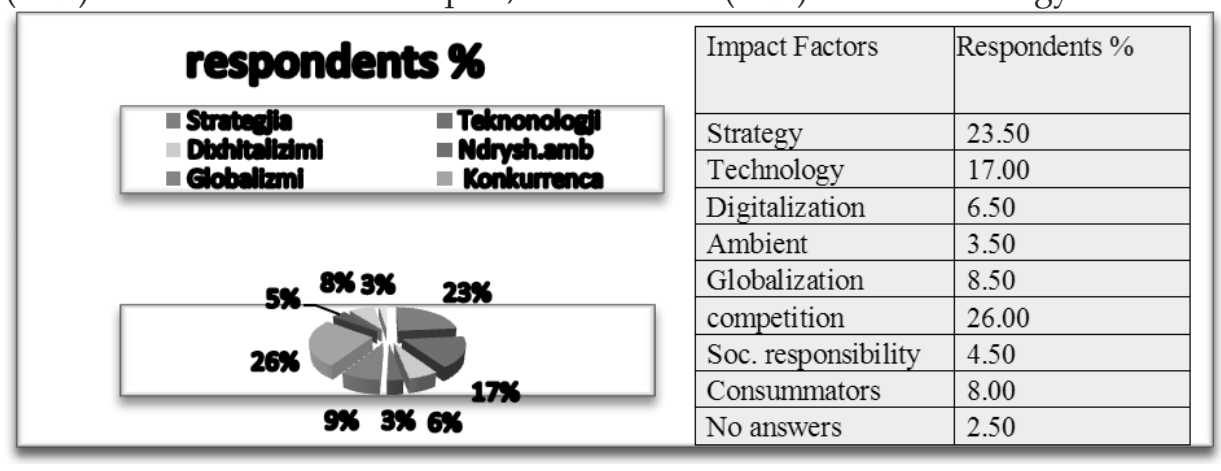

Fig. 3. Adaption Structure impact factors. Source: Authors`research.

Tab. 2. Adaption Structure impact factors.

To the Question no 23: How much do you know about business organizational structure?

The answer "I have average knowledge "is given of the $38 \%$ respondents only. (See the table no 3). 
Tab. 3. Respondents' opinion about awareness of management class in terms of organizational structure.

\begin{tabular}{|l|l|c|c|}
\hline $\mathrm{nr}$ & Alternatives & Frequency & Percent \\
\hline 1 & Nothing & 10 & 5.0 \\
\hline 2 & Very little & 30 & 15.0 \\
\hline 3 & A little & 31 & 15.5 \\
\hline 4 & On the average & 76 & 38.0 \\
\hline 5 & Most & 40 & 20.0 \\
\hline 6 & Everything & 13 & 6.5 \\
\hline & Total & 200 & 100.0 \\
\hline
\end{tabular}

Source: Authors` research.

Based on the data we can say so that there is little awareness of the Albanian managers' class on the importance of the structure.

To the Question no 24: How much do you know about business organizational strategy?

We have even a worse situation as the structures case. The answer "I have average knowledge "is given of the $27.5 \%$ respondents only (see the table no 4 ).

Tab. 4. Respondents' opinion about awareness of management class in terms of organizational strategy.

\begin{tabular}{|c|l|c|c|}
\hline $\mathrm{nr}$ & Alternatives & Frequency & Percent \\
\hline 1 & Nothing & 7 & 3.5 \\
\hline 2 & Very little & 38 & 19.0 \\
\hline 3 & A little & 49 & 24.5 \\
\hline 4 & On the average & 55 & 27.5 \\
\hline 5 & Most & 38 & 19.0 \\
\hline 6 & Everything & 13 & 6.5 \\
\hline & Total & 200 & 100.0 \\
\hline
\end{tabular}

Source: Authors`research.

\section{CONCLUSION}

From the study conducted, we found that despite changes which have occurred in recent years in Albania, and in particular in Vlora, we still do not have a managers' awareness of the importance of an organizational structure. Some of the reasons why human resource management is conducted by private firms operating in the city of Vlora can also be found in staff development problems faced by these firms during the transition period to an economy market.

Nevertheless, we found some impact of the Strategy on the organizational structure. The already complex environment - which is becoming increasingly dynamic - and growing competition, is changing the way in which work is organized, together with relevant solutions. The factors with the greatest impact on 
organizational structuring are competition first, and then strategy. The financial ability is noticed as the most challenging factor conditioning structuring and organizational decision processes. The models are conditioned by several factors (Size / Age of Org. / Awareness of the impact on performance).

Great opportunities are arising from a better understanding of contemporary organizations and the work environment.

To take advantage of these opportunities, trends regarding the relationship between organizational design and design work should be studied and identified. In such a chain structure takes a more central position. Its task is to translate strategy into organizational levels. If management makes serious mistakes in the translation, it can be difficult to achieve the goals set by it. In order to design organizations that will be able to successfully confront upcoming competition and increasing changes in consumer expectations, it is necessary to look for systemic and cause-and-effect relationships between emerging practice at various levels of analysis - industry, organization, and work.

\section{REFERENCES}

Burton R. M., Obel B., (2004), Strategic Organizational Diagnosis and Design: The dynamic of fit. New York: Springer.

Burton R. M., Eriksen B., Døjbak Håkonsson D., \& Snow Ch. C. (2006), Organization Design: The Evolving State-of-the-Art. New York: Springer.

Daft R. L., \& Armstrong A. (2012), Organization Theory and Design, Canada: Nelson Education Ltd.

Harmon P. (2003), Business Process Change; A Manager's Guide to Improving, Redesigning, and Automating Processes. California: Morgan Kaufmann Publishers.

Rummler G, \& Brache A. P. (1995). Improving Performance: How to Manage the White Space on the Organization Chart. New Jersey: Wiley \& Sons, Inc.

Rummler G, \& Brache A. P. (2013). Improving Performance: How to Manage the White Space on the Organization Chart. New Jersey: Wiley \& Sons, Inc.

Grant R. M. (2009). Contemporary Strategy Analysis New Jersey: Wiley \& Sons.

Radzi S. M., Jamaluddin M. R., Zahari M. S. M., Amran, \& Othman Z. (2007), Empirical Assessment of Business Strategy and Structure Relationship of 3-Star Hotels in Malaysia, TEAM Journal of Hospitality \& Tourism, 4/1, 1-11.

Tomislav H. (2011) Business Trends and Tendencies in Organization Design and Work Design Practice: Identifying Cause-and-Effect Relationships. FEB-Working Paper series,11-03, 1-18. 